\title{
Antonio Brand
}

\author{
Egydio Schwade*
}

Antonio Brand entrou no Noviciado dos Jesuítas em Porto Alegre, RS, por volta de 1967. Em abril daquele ano Thomaz Lisboa e eu, também seminaristas jesuítas, cursando Teologia, fizemos uma Semana Santa diferente. Fomos visitar aldeias indígenas no interior do RS. De volta, escrevemos uma série de nove artigos sob o título: Drama de 1.080 famílias Indígenas do Rio Grande do Sul, que publicamos no Jornal Correio do Povo, de Porto Alegre. A série teve bastante repercussão e provocou uma Comissão Parlamentar de Inquérito na Assembleia Legislativa do estado. Como consequência, esta desencadeou, um mês depois, outra CPI na Câmara Federal o que se estendeu a todo o país, provocando a queda e substituição do Serviço de Proteção ao Índio (SPI).

A série de artigos agitou também o Noviciado dos jesuítas e recebi uma carta de Antonio Brand e Ivo Schroeder, na qual eles se dispunham a fazer pesquisa semelhante a que Thomaz e eu havíamos feito no RS, em aldeias do leste catarinense, durante as suas férias de 1968. Trouxeram assim à luz a realidade indígena dos índios Xokleng e Guarani do Vale do Itajaí.

Essas duas pesquisas sobre a situação dos índios no sul do Brasil e a experiência que Thomaz e eu havíamos feito no nosso estágio de três anos na Missão Anchieta dos jesuítas, em Mato Grosso, convenceu-nos da necessidade de se mudar a Política Indigenista dentro da Igreja Católica. Sentíamos uma necessidade urgente de mais pessoas, e de pessoas com mais disponibilidade e mais agilidade, e com uma "visão nacional e até internacional" da questão indígena. Tal mudança na Igreja só vislumbrávamos envolvendo jovens leig@s e jovens religios@s dos seminários e juvenatos. Foi para isso que criei a OPAN, Operação Anchieta, hoje Operação Amazônia Nativa, em fevereiro de 1969. Após a sua criação continuei mantendo íntimo contato com os estudantes jesuítas do noviciado, que visitava toda a vez que podia. Deles recebi logo todo o apoio, principalmente de Antônio e Ivo, que resolveram sair da Ordem para poderem ficar mais disponíveis, a serviço do seu ideal missionário, objetivo de sua vida que, na Ordem, viam muito distante.

* Casa da Cultura do UrubuíCacuí
Tellus, ano 12, n. 23, p. 243-245, jul./dez. 2012

Campo Grande, MS 
O apoio que a OPAN recebeu daquele grupinho de jesuítas e da família Bonotto, do Morro dos Alpes em Porto Alegre, naqueles inícios, motivou a transferência da sua sede de São Bento do Sul/SC, para Porto Alegre, em 1971. Antônio e Ivo entraram na OPAN e, já naquele ano, fizeram o curso de indigenismo na cidade de Lajeado, RS.

A OPAN teve logo um forte impulso e cresceu em todas as direções: aumento de voluntários e voluntárias, crescimento em ecumenismo unindo jovens católicos e evangélicos, voluntári@s austríac@s da ÖED-Öesterreichische Entwicklungsdienst e italian@s da TVC-Tecnici Voluntarii Cristiani, podendo abrir novas frentes em muitas comunidades indígenas carentes.

Quando o CIMI foi criado em 1972, após um ano de sua fundação ainda vegetava sem ação indigenista, como mero Conselho Institucional e, em junho de 1973, o seu Secretariado Executivo, foi a OPAN, já com Antonio Brand na sua coordenação, que forneceu o maior número de voluntários para os primeiros sete anos de funcionamento do Secretariado do CIMI. Nesse tempo, a OPAN organizou também o primeiro boletim indigenista: o MACAXEIRA que visava à comunicação entre os seus voluntários. Ivo Schroeder, sempre ao lado de Antônio na coordenação da OPAN, foi quem se tornou a alma do boletim, o qual teve tanto sucesso entre os missionários indigenistas, não só leigos mas também religiosos e índios, que na Primeira Assembléia Nacional do CIMI, em 1975, esta solicitou que o MACAXEIRA deixasse de existir e transferisse a sua equipe de redação para o Secretariado Nacional do CIMI. A sugestão foi generosamente aceita pela coordenação da OPAN, e Ivo Schroeder e família se transferiram para Brasília onde passaram a redigir o Boletim do CIMI.

Insisto na presença de Antônio na coordenação da OPAN, porque a sua ação ali, como a de muitos de seus coleg@s leig@s foi fundamental no primeiro impulso à renovação da política indigenista da Igreja Católica, dentro dos princípios delineados pelo Concilio Vaticano II. Enquanto os Bispos que assinaram o documento e o clero ainda se debatiam em longas discussões e realizavam cursos de meses e até anos para atualizar o clero, preso a uma Igreja instituição pré-conciliar, Antonio Brand, Ivo Schroeder, Darci Secchi, Ivar Busatto, Egon Heck e Gunter Francisco Loebens deixavam suas respectivas instituições para com coleg@s leig@s puxarem a fila de um grupo de jovens que se engajavam na perspectiva da visão conciliar da Igreja, não Instituição, mas povo de Deus.

A decisão dessa juventude tirou o CIMI do marasmo inicial tanto em sua ação nas aldeias indígenas, como na dinâmica que seus membros imprimiram na equipe central do seu Secretariado Executivo Nacional em seus primeiros sete anos de existência.

Desde que o CIMI se tornou um órgão vinculado a Conferência Nacional dos Bispos do Brasil, tende-se a dar um caráter muito clerical e institucional 
a ação do órgão e inclusive de seus membros leig@s. Na vida de Antônio, como desses outr@s colegas citados, fica muito claro que a decisão da sua saída das instituições religiosas clericais lhes deu a liberdade interior de se colocarem a serviço da Igreja Povo de Deus mais necessitado, quando foram enriquecer suas vidas das "sementes do Verbo ocultas", dentro das linhas de ação do Concílio Vaticano II. Essa meia dúzia de seminaristas que abandonou a caminhada iniciada em instituições religiosas e engrossou a recém-criada OPAN, deu asa livre às suas vocações que os empurraram Brasil afora onde colaboraram decisivamente na transformação histórica da catequese indigenista da Igreja em anúncio de Boa Nova aos povos indígenas, animando-os na conquista da Terra, na volta à sua Cultura e na reconquista da sua Autodeterminação. Nessa caminhada da Igreja, Antônio teve em toda a sua caminhada missionária um papel muito preponderante.

Casa da Cultura do Urubuí, 13 de fevereiro de 2013. 
